\title{
MEANS OF INTERPRETATION OF INTERNATIONAL TREATIES AND DETERMINANTS OF THEIR SIGNIFICANCE ${ }^{1}$
}

\begin{abstract}
The choice of means of interpretation and attribution appropriate weight to them may well determine the outcome of an interpretation. Articles 31 of the 32 of the VCLT leave broad discretion to an interpreter in that respect. That may turn an interpretation into a legal process of diminishing predictability and undermine legal certainty. Judicious discretion in the choice and weighing means of interpretation should not be unlimited. The nature and particular characteristics of a treaty, of a question that should be answered by interpretation, and of the means of interpretation, might have the role of determinants of the significance of means of interpretation. The correlations in a triangle of the particular characteristics of the treaty, the question and the means of interpretation, established as typical in the practice of international courts, might constitute a standard model of interpretation. An international court would be expected to explain its departure from the model.
\end{abstract}

Keywords: international treaties, means of interpretation, significance.

\section{INTRODUCTION}

We expect that the information that we receive from the particular provision of a treaty, from its preamble and annexes and from its object and purpose as well as from the preparatory work or from the practice in the application of a treaty to be harmonies as they all flow from the same source - that being the common intention and common understanding of the parties. Unfortunately, due various factors, occasionally this does not occur. Cases arise where there was no concordant intention of the parties on the specific issue at the time of the conclusion of a

\footnotetext{
${ }^{1}$ This research has been rendered in the framework of the research project "Legal Tradition and New Legal Challenges" financed by the Faculty of Law of the Novi Sad University.
} 
treaty and the vague text conceals the absence of the agreement. The parties achieved a concordant intention although its textual expression is defective and does not fully manifest the common intention. Or, over time, due to changed social circumstances, the concordant practice in the application of the treaty reflects a new common understanding of the parties differing from the original. There may be other reasons to consider but in a situation of contradictory information we have the problem. We can try, if it is possible to harmonize them. But, if it is not possible, we must weight them and decide which of them have greater weight.

Articles 31 and 32 of the Vienna Convention on the Law of Treaties (hereinafter: the VCLT) enumerate some means for the determination of the meaning of the treaty, but they do not enumerate all means. The same Articles establish certain hierarchical relationship between the means indicated in the first and second Article, but they do not determine the relative weight of each of them and the superiority of some over others in the case of their mutual disharmony. Thus, the Articles leave a rather broad discretion to the interpreter in respect to the choice of means, their weighing and resolving any potential disharmony among them. That broad discretion undermines predictability and certainty in interpretation of international treaties and just these values are the rationale of the rules on interpretation. If we do not know in advance the means to be used and in the case of disharmony, what will have greater weight, we are unable to predict the outcome of interpretation. Further, we cannot predict the legal effects of the treaty in the specific situation and consequently whether our attitude will be in accordance with the treaty or not.

The text explores whether it is possible to establish objective determinants to the relevance and weight of various means. The brief analysis of Articles 31 and 32 of the VCLT will cast some light on their content and elements relevant for the exploration of the topic of this text. A short indication of the importance of the topic will be given and a hypothesis concerning the exploration will be exposed. Since the interpretation comprehends searching for the answer to a question appeared in the application of the treaty by using means of interpretation - the hypothesis is that determinants of the significance of means of interpretation have to be searched for in a triangle of particular characteristics of the treaty, of the question and of the means. The hypothesis will be explored in respect to the constituent acts of international organizations, the European Convention on Human Rights and the investment treaties.

\section{BRIEF ANALYSIS OF ARTICLES 31 AND 32 OF THE VIENNA CONVENTION ON THE LAW OF TREATIES}

Principles, rules, methods, evidences, sources, elements, techniques, maxims etc. are legal terms, used concerning the interpretation of international treaties, to denote same or different things. But, the content of Articles 31 and 32 of the 
VCLT might be decomposed to the evidences of facts relevant for interpretation and the methods of choosing, treatment and weighing evidences. ${ }^{2}$

The text of a treaty, the preamble, annexes or preparatory work are expressions of the intention of the parties and these documents or their parts can be named evidences of intention. Subsequent agreement on the interpretation of a treaty or subsequent practice in the application of a treaty reflects an understanding of the text of a treaty by the parties and these acts can be denoted as evidences of understanding. The border between these two groups of evidences is not always clear cut, but in this text intention is connected with the creation of an international treaty and understanding with the application of the treaty. Circumstances of the conclusion of a treaty or rules of international law applicable between the parties may be labeled as evidences of matters which may influence the intention or understanding of the parties and thus might clarify their expressions.

Article 31 of the VCLT refers to good faith and that reference might be taken as a general method of interpretation. References to ordinary or special meaning and to the context, object and purpose might be titled as particular methods. Methods instruct us how to deal with evidences, how to establish interaction among them. The means of interpretation will be used in this text as generic term that covers evidences and methods.

Using an exhaustive method of enumeration, Article 31, limits "general rule," to some means of interpretation. Contrary, following an exemplary method of enumeration, ${ }^{3}$ Article 32 under the tile "Supplementary means of interpretation," leaves discretion of using, beside the preparatory work and the circumstance of the conclusion of a treaty, also other evidences and methods.

Article 32 of the VCLT determines two conditions under which supplementary means are applicable. The first condition enables that interpreter uses supplementary means "to confirm the meaning resulting from the application of Article 31." The second condition relates to incapacity of Article 31 to produce sufficiently clear meaning. When interpretation according to Article 31 results in an ambiguous, obscure, manifestly absurd or unreasonable meaning then the interpreter will apply supplementary means. Thus the interpreter may apply supplementary means always, but the text of Article 32 implies that interpreter is not obliged to use them, if application of Article 31 results in a sufficiently clear meaning. That implies certain superiority of means provided in Article $31 .^{4}$ The

\footnotetext{
${ }^{2}$ See the review of Articles $31-32$ of the VCLT at M. E. Villiger, The Rules of Interpretation: Misgivings, Misunderstandings, Miscarriage? The "Crucible" intended by the International Law Commission, in E. Cannizzaro (ed.), The Law of Treaties Beyond the Vienna Convention, 2011, 108-114.

${ }^{3}$ L. Sbolci, Supplementary Means of Interpretation, in E. Cannizzaro (ed.), supra note 1, 151.

${ }^{4}$ U. Liderfalk, Is the Hierarchical Structure of Article 31 and 32 of the Vienna Convention Real or Not? Interpreting the Rules of Interpretation, Netherlands International Law Review, 1/2007, at 133 - 154, L. Sbolci, supra note 2, 147, 149.
} 
International Law Commission (hereinafter: the ILC) made distinction between primary means of interpretation from Article 31, which all have to be taken into account in the process of interpretation, and supplementary means of interpretation from Article 32.5 Beyond that very modest indication of hierarchy among various evidences and methods of interpretation, the issue of the hierarchical order among them has not been further governed by Articles 31 and 32.

Working on the codification of the rules on interpretation in $1964-1966$, the ILC was very careful not to prejudice the issue of hierarchy among different means. In its Commentary of 1966 the Commission was explicit that successive order of the paragraphs in Article 31 (then it was Article 27) did not mean hierarchical order of the application of elements indicated in them. ${ }^{6}$ It stressed that "that the application of the means of interpretation in the article would be a single combined operation" " and that "all the various elements, as they were present in any given case, would be thrown into the crucible, and their interaction would give the legally relevant interpretation." 8 Further, the ILC explained that line of division between supplementary means and those primary from Article 31 (then 27 Article) was not rigid and that confirmatory function of supplementary means "establishes a general link between the two articles and maintains the unity of the process of interpretation." 9

The issue of significance of different means of interpretation was discussed in the Commission and was object of comments of Governments, but it was not addressed by the Commission much more beyond above stated observations and it was not governed by the proposed Articles beyond the classification into general rule of interpretation and supplementary means. Having returned to the issue of subsequent agreements and subsequent practice in the application of a treaty as means of interpretation in 2013, the ILC has started to consider the issues of relevance, weight and significance of different means of interpretation.

\section{IMPORTANCE OF THE ISSUE}

The non-settled issue of determinants of the choice and hierarchical order of means of interpretation is of remarkable importance. Usually, interpreter has at disposal more evidences and methods. Frequently, they can be in disharmony and the choice some among them, or attributing more weight to some result in different interpretation of the same treaty provision. Due to that reason the ICJ inter-

\footnotetext{
${ }^{5}$ Report of the ILC, 2016, 125.

${ }^{6}$ Yearbook of the ILC, 1966, vol. II, 219.

${ }^{7}$ Ibid.

${ }^{8}$ Ibid., at para. 8 .

${ }^{9}$ Ibid., at 220, para. 10 .
} 
preted the same provision differently in different phases of the proceedings ${ }^{10}$ or two ICSID tribunals, ${ }^{11}$ in two cases of comparable facts, interpreted the same provision of the bilateral investment treaty differently.

The fact that the issue of determinants of significance of various means of interpretation has not been settled, or at least not in satisfactory way, before and after the codification of the Treaty Law, and that leaves a broad discretion to interpreter, caused sharp criticism. H. Lauterpacht wrote: “... as a rule they (rules of interpretation) are not the determining cause of judicial decision, but the form in which the judge cloaks a result arrived at by other means... it is a fallacy to assume that the existence of these rules is a secure safeguard against arbitrariness or partiality." 12 But, he continued: "the examination must be directed not so much to a criticism of rules of interpretation in general, or of their number, as to the accuracy of particular rules, the manner of their application, and their hierarchical importance when viewed in their totality." The unsettled issue has remained the constant object of observation and dissatisfaction in the literature. ${ }^{13}$ The sharpest in criticism was probably Bianchi, who compared interpretation with playing cards and observed:

"...the most well-known version of the game relies on the VCLT cards. Such unconditional success is hardly surprising, as the flexibility of the system is such that recourse to the VCLT accommodates practically all approaches to interpretation. The principles and rules of the VCLT can be twisted and bent, turned upside down and the criteria codified in it can be prioritized to one's liking." 14

Normative fixing determinants of significance of evidences and methods of interpretation would serve legal predictability and certainty. However, the issue

${ }^{10}$ Case concerning Application of the International Convention on the Elimination of All Forms of Racial Discrimination (Georgia v. the Russian Federation), Order on preliminary measures , 15 October 2008; Application of the International Convention on the Elimination of All Forms of Racial Discrimination (Georgia v. Russian Federation), Preliminary Objections, Judgment, 1 April 2011, ICJ Reports, 2011, 70. available online at: http://www.icj-cij.org/docket/ files/140/14801.pdf (last visited 16 June 2017)

${ }^{11}$ ICSID Kılıç İnşaat İthalat İhracat Sanayi ve Ticaret Anonim Şirketi v. TurkmenistanAward, 2 July 2013, ICSID Case No. ARB/10/1.; ICSID Sehil Inşaat Endustri ve Ticaret Ltd. Sti. v. Turkmenistan, Decision on Jurisdiction, 13 February 2015, ICSID Case No. ARB/12/6.

${ }^{12} \mathrm{H}$. Lauterpacht, Restrictive Interpretation and the Principle of Effectiveness in the Interpretation of Treaties, British Yearbook of International Law, 1949, 53.

${ }^{13}$ D. French, Treaty Interpretation and the Incorporation of Extraneous Legal Rules, International and Comparative Law Quarterly, 2/2006, 281; U. Linderfalk, Is Treaty Interpretation an Art or a Science? International Law and Rational Decision Making', European Journal of International Law, 1/2015, 175; A. Bianchi, The Game of Interpretation in International Law in A. Bianchi, D. Peat and M. Windsor, (eds), Interpretation in International Law , 2015, 44.

${ }^{14}$ A. Bianchi, supra note 12. 
is whether such general normative regulation is possible and whether it would be useful? There are views that over-regulating process of interpretation might be counterproductive. ${ }^{15}$ Commenting on the Draft of the ILC from 1964, one Government observed that the Commission "endeavoured to encroach as little as possible on the freedom of the interpreter" ${ }^{16}$ considering obviously that freedom in interpretation exists. There is the view that "determination of the hierarchical importance or relevance" of evidences and methods relevant for interpretation in advance in general way is also counterproductive: "The point to be stressed is that prior to a comprehensive contextual examination no determination of the hierarchical importance or relevance of any feature of the context may be usefully made, and any attempt to do so must ultimately frustrate the ascertainment of genuine shared expectations." ${ }^{17}$ The US delegation at the Vienna Conference on the Law of Treaties considered that the draft rules on interpretation, prepared by the ILC, were too rigid and proposed more flexibility, but the proposal was rejected. ${ }^{18}$

The issue is whether it is possible to define general determinants valid in each case of interpretation or whether each case of interpretation requires its particular determinants? G. Nolte refers to particular circumstance of the case and of the treaty: "Articles 31-33 VCLT do not set up a rigid system, or method, of interpretation, but rather offer a range of means of interpretation whose relative importance must be assessed in a holistic fashion in the light of the particular circumstances of the case and of the treaty concerned." 19

Interpretation in practice is employment of means of interpretation with the aim that the treaty provides a reply to the question that has appeared in its application. Thus, hypothetically, general determinants of the relevance and weight of means of interpretation might be found in the triangle of the treaty, the raised question and the means of the interpretation. The following text aims to explore the relevance of these three angles in the establishment of the determinants of the significance of the means of interpretation. However, it will be seen that some factors beyond the triangle have also been distinguished as relevant for interpretation.

${ }^{15}$ G.G. Fitzmaurice, The Law and Procedure of the International Court of Justice: Treaty Interpretation and Certain Others Treaty Points, British Yearbook of International Law,1951, 2.

16 YILC, supra note 5, at 336.

${ }^{17}$ M. S. McDougal, H. D. Lasswell and J. C. Miller, The Interpretation of Agreements and World Public Order, 1967, 96.

${ }^{18}$ G.A.G. Gottlieb, The Interpretation of Treaties by Tribunals, American Society of International Law Proceedings, 1969, 122; M. E. Villiger, Commentary on the 1969 Vienna Convention on the Law of Treaties, 2009, 424.

${ }^{19} \mathrm{G}$. Nolte, Subsequent Practice as a Means of Interpretation in the Jurisprudence of the WTO Appellate Body, in E. Cannizzaro (ed.), supra note 1, 140. 


\section{CLASSIC DOCTRINE OF FAVOURABLE AND ODIOUS THINGS}

The classics created doctrine on the relevance of the distinction between favourable and odious things for choosing between an extensive or restrictive interpretation. Having observed that "many Words have several Significations, one more strict and precise, the other more loose and extensive," 20 Grotius held that the nature of a promise should determine the choice between a restrictive and extensive meaning. The promise of favourable nature requires extensive interpretation and the promise of an odious nature demands restrictive interpretation. Grotius wrote: "In cases not odious we must understand the words in their full extent, as they are generally taken; and if they are ambiguous, then they must be taken in the largest sense". ${ }^{21} \mathrm{He}$ explained that: "The favourable are those that carry in them an Equality, and respect the common Advantage, which the farther it extends, the greater is the Favour of the Promise, as in those that make for Peace the Favour is greater than in them that make for War;..."22 Thus, Grotius thought that the "nature of a promise" can determine the choice between an extensive and a restrictive interpretation, but only in the limits of the text. Pufenedorf followed Grotius in that doctrine, ${ }^{23}$ but Vattel brought the innovation.

If the expression of the parties are "indeterminate, vague, or susceptible of a more or less extensive sense" and "precise point of their intention cannot, in the particular case of question, be discovered and fixed by other rules of interpretation," Vattel considered that reason and equity advise the determinative importance of distinction between favourable and odious matters as the presumed intention of the parties. ${ }^{24}$ Without pretension to be exhaustive in enumeration of favourable and odious matters Vattel sorted those tending to common advantage and equality, ${ }^{25}$ those useful for human society ${ }^{26}$ among favourable and those that contain a penalty ${ }^{27}$ or render the deed void ${ }^{28}$ among odious. Vattel relocated effects of the

${ }^{20}$ H. Grotius, The Rights of War and Peace, 1625, translated from Latin into English by J. Barbayrac, (1738), digitized by the Internet Archive in 2011, second b., ch. XVI, para. IX, at 356 available at https://archive.org/details/rightsofwarpeace00grot (last visited 16 June 2017)

${ }^{21}$ Ibid., para. XII, at 357.

22 Ibid., para. X, at 356.

${ }^{23}$ S. Pufendorf, Of the Law of Nature and Nations, translated by B. Kennett (1729) b. V, ch. XII, at 542, 543, paras XII, XIII. Available at https://archive.org/details/oflawofnaturenat00pufe (last visited 16 June 2017)

${ }^{24}$ E. Vattel, The Law of Nations or Principles of the Law of Nature Applied to the Conduct and Affairs of Nations and Sovereigns, from the new edition by J. Chitty (1852) b. III, ch. XVII, at 363, para. 300. Available at https://ia800203.us.archive.org/19/items/lawofnationsorpr00vatt/ lawofnationsorpr00vatt.pdf (last visited 16 June 2017)

${ }^{25} \mathrm{Ibid}$., at 364, para. 301.

${ }^{26}$ Ibid., at 365, para. 302.

${ }^{27}$ Ibid., para. 303.

${ }^{28}$ Ibid., para. 304. 
doctrine of favourable and odious matter beyond the limits of the text, but he saw the doctrine as the last means of interpretation, allowed when all others were incapable of determining the "precise point" of intention of the parties.

The references to favorable and odious matters disappeared later in literature, but the issue whether the nature of subject-matter of the obligations, accepted by a treaty, are of relevance for interpretation of international treaties has remained actual.

\section{PARTICULAR CHARACTERITICS OF MULTILATERAL TREATIES}

Classics thought that the nature of the subject-matter of an obligation was a factor that could determine interpretation. Changes within the international community over time have influenced the consideration of the issue. The expansion of multilateral treaties, raising the prominence of law-making treaties and constituent acts of international organizations initiated doctrinal discussion and practical solutions related to the relevance of characteristics and types of international treaties as determinants of significance of various means of interpretation. The question - whether fragmentation of international law is manifest also in "the emergence of different hermeneutics across the landscape of judicial treaty interpretation?"29- has become actual.

Q. Wright drew the distinction between "law-making" and other treaties, comparing the first with domestic statues and the second with private contracts. ${ }^{30}$ Having observed that statements of intention in legislative debate in parliament's bodies or correspondence between their members have little weight in interpretation of statutes, ${ }^{31}$ Wright also observed that it was not common to use preliminary materials, except formally attached reservations, for the interpretation of multilateral law-making treaties. ${ }^{32}$

Critics of the intentional approach will extend this view to all multilateral treaties and add new arguments. "The mixed aims, motives, interests, and ideologies" of the countries participating in preparation and adoption of multilateral conventions, "the haste and confusion in which multilateral conventions are often drawn up," "the fact that States may accede to these conventions many years after they were originally drawn up", when practice in the application pushed aside original intention of drafters, "render the very notion of the intentions of the par-

${ }^{29}$ J.H.H. Weiler, The Interpretation of Treaties - A Re-examination, Preface, European Journal of International Law, 3/2010, 507.

${ }^{30} \mathrm{Q}$. Wright, The Interpretation of Multilateral Treaties, American Journal of International Law,1929, 94.

${ }^{31}$ Ibid., at 97.

${ }^{32}$ Ibid., at 103 . 
ties artificial." ${ }^{33}$ The consequence of such criticism might be that the preparatory work, as the evidence of original intention of the parties, is inferior to the practice in the application of a treaty which reflects a contemporary understanding of the text. P-M. Dupuy distinguishes "a treaty that establishes an organization designed to achieve a shared purpose" and contends that such treaties place the judge in a position of an organ of community who will interpret the treaty pursuant to the communal interests furthering the collective plan. ${ }^{34}$

\section{CONSIDERATION OF THE ISSUE BY THE INTERNATIONAL LAW COMMISSION}

In the First report on subsequent agreements and subsequent practice in relation to treaty interpretation ${ }^{35} \mathrm{G}$. Nolte, Special Rapporteur presented a concise review of application of Articles 31 - 33 of the VCLT by different international courts, tribunal and quasi-judicial bodies. The review shows that different courts or tribunals use some means much more frequently than others. ${ }^{36}$ Except the ICJ, jurisdiction ratione materiae of other courts, tribunal or quasi-judicial bodies are limited to one or a few conventions similar in nature. Consequently, it might be presumed that the nature and particular characteristics of these conventions determine the selection of means. Bearing this in mind, most probably the Special Rapporteur proposed the following as Paragraph 2 of Draft conclusion 1: "The interpretation of a treaty in a specific case may result in a different emphasis on the various means of interpretation contained in articles 31 and 32 of the Vienna Convention, in particular on the text of the treaty or on its object and purpose, depending on the treaty or on the treaty provisions concerned."

It seems that the Special Rapporteur considered that the treaty or the treaty provision can determine significance of various means of interpretation. After discussion in the ILC, Paragraph 2 of Draft conclusion 1 has become Paragraph 5 of Draft conclusion 2, which states that the interpretation comprehends "single combined operation, which places appropriate emphasis on the various means of interpretation, ${ }^{\prime 37}$ but reference to the treaty or the treaty provision was removed to the Comments. ${ }^{38}$ Paragraph 15 of the Comments is important also by explana-

${ }^{33}$ G.G. Fitzmaurice, supra note 14, at 3.

${ }^{34}$ P.M. Dupuy, Evolutionary Interpretation of Treaties: Between Memory and Prophecy, in E. Cannizzaro (ed), supra note 1, at 126.

${ }^{35}$ ILC, A/CN.4/660. 19 March 2013.

${ }^{36} \mathrm{Ibid}$., at paras $10-27$. See review of the choice of means of interpretation by different international courts and tribunals at E. Villiger, supra note 1, at $115-116$.

${ }^{37}$ RILC, supra note 4 , at 120 , para. 16.

${ }^{38} \mathrm{Ibid}$., at 131, para. 15. 
tion that the interpreter is not free "to choose how to use and apply the different means of interpretation." 39 The interpreter is invited to identify "the relevance of different means of interpretation in a specific case" 40 and to weight each of them in good faith and in such a way as to determine their mutual interaction. By doing so, the interpreter should rely on previous assessments in the same or other relevant areas. ${ }^{41}$

The ILC discussed the issue whether the nature of the treaty is capable of determining the significance of different means of interpretation. Some members of the ILC thought that "the subject matter of a treaty", its content consisting of economic matters or human rights provisions or technical or value-oriented provisions might be relevant for interpretation. ${ }^{42}$ Also, they considered that "basic structure and function" of a treaty, whether a treaty is based in concept of reciprocity or in a common good could influence its interpretation. ${ }^{43}$ They found support for such views in the jurisprudence of different international courts and tribunals. The other members opposed arguing that the "nature of the treaty" was not enough a clear concept and that it is inseparable from the object and purpose of a treaty. ${ }^{44}$ The ILC left, for the time being, the question open.

\section{AN INTERPRETATIVE MODEL FOR CONSTITUENT ACTS OF INTERNATIONAL ORGANIZATIONS}

Exploration of the interpretative practice of different international courts have shown the existence of certain correlations between the nature and other particular characteristics of the treaty and the employed means of interpretation, which is visible in statistics of employed means: some means of interpretation are used much more frequently than others and some means are attributed with greater weight than others. The correlation does not mean that interpreter has to apply only those frequently applied means and that rarely employed means should not be applied at all, but it can result in a model consisting of usually employed means and usually attributed weight. The model can serve as grounds for the expectation concerning the interpretation. The ILC emphasized the importance of consistency in interpretation advising the interpreter to rely on previous assessments of significance of means of interpretation in the same or other relevant areas. ${ }^{45}$

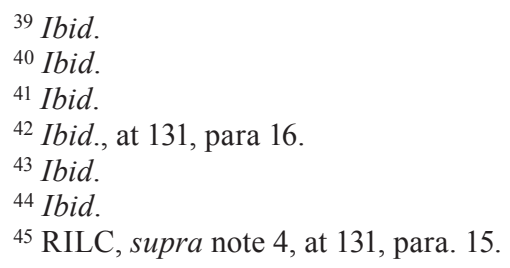


The ICJ considered the issue of relevance of particular characteristics of constituent acts of international organizations for their interpretation in the Advisory Opinion of Legality of the Use by a State of Nuclear Weapons in Armed Conflict:

“... the constituent instruments of international organizations are ... treaties of a particular type; their object is to create new subjects of law endowed with a certain autonomy, to which the parties entrust the task of realizing common goals. Such treaties can raise specific problems of interpretation owing, inter alia, to their character which is conventional and at the same time institutional; the very nature of the organization created, the objectives which have been assigned to it by its founders, the imperatives associated with the effective performance of its functions, as well as its own practice, are all elements which may deserve special attention when the time comes to interpret these constituent treaties." ${ }^{\prime 46}$

Consequently, the new subject of law enjoys "certain autonomy" also in interpretation of the constituent act and therefore acts of the organs of an organization have particular weight as evidence of their understanding of the constituent act. The ICJ concluded that the nature of the organization, the objectives, the effectiveness, and the practice of the organization have particular weight.

The Court referred further to the customary rule of interpretation, as stated in Article 31 of the VCLT, and quoted the following text from the Article: "the terms of a treaty must be interpreted 'in their context and in the light of its object and purpose' and there shall be 'taken into account, together with the context:. . . (b) any subsequent practice in the application of the treaty which establishes the agreement of the parties regarding its interpretation". ${ }^{47}$ It is remarkable that the Court omitted to mention "ordinary meaning". The ICJ continued by referring to four previous cases where the rule was applied, ${ }^{48}$ but in all of them the method of ordinary meaning was mentioned and two of them were focused on that method. The issue is whether the Court by such textual arrangement indicated some preference of the mentioned elements over those omitted?

${ }^{46}$ Legality of the Use by a State of Nuclear Weapons in Armed Conflict, Advisory Opinion, 8 July 1998, I C J Reports, 1996, 75.

${ }^{47}$ Ibid.

48 The passage states: 'The Court has had occasion to apply this rule of interpretation several times (see Arbitral Award of 31 July 1989 (Guinea-Bissau v. Senegal), Judgment, I.C.J. Reports 1991, pp. 69-70, para. 48; Land, Island and Maritime Frontier Dispute (El Salvador/Honduras: Nicaragua intervening), Judgment, I. C.J. Reports 1992, pp. 582-583, para. 373, and p. 586, para. 380; Territorial Dispute (Libyan Arab Jamahiriya/Chad), Judgment, I.C.J. Reports 1994, pp. 21-22, para. 41; Maritime Delimitation and Territorial Questions between Qatar and Bahrain (Qatar v. Bahrain), Jurisdiction and Admissibility, Judgment, I. C. J. Reports 1995, p. 18, para. 33);..' Legality of the Use by a State of Nuclear Weapons in Armed Conflict, supra note 45, at 75. 
The hypothesis that the context, object and purpose as the methods of interpretation and subsequent practice in the application of the treaty as evidence of contemporary understanding of the treaty have particular significance in the interpretation of these treaties might have some support in the practice of the PCIJ and the ICJ.

The analysis of the relevant interpretative practice of the two World Courts, the PCIJ and the ICJ, shows the purpose, object and context will prevail over the opposite text of particular provision. In the Advisory Opinion on the issue whether the competences of the ILO include conditions of work in agriculture, the PCIJ interpreted, by some support in dictionaries, adjective "industrial," which appeared in some provisions of Part XIII of the Versailles Peace Treaty, then constituent act of the ILO, broadly to cover agriculture. ${ }^{49}$ Terms "persons of industrial experience", and in the French version "personnes compétentes en matières industrielles," indicating qualification for the membership in a Commission of Enquiry for compliance of the parties with the ILO Conventions, as foreseen in Article 412 of Part XIII, were particularly in disharmony with the purposes of Part XIII. Interpreting the phrase in the context of the whole Part XIII, the Court concluded that intention of the parties was that the phrase include "the industry of agriculture", but the Court did not hesitate to add "even if it were not so read the consequences would be that there would seem to be merely a defect in the constitution of the machinery in this particular instance, and not that the powers given to the international organisation with regard to conditions of labour were to be similarly limited." ${ }^{50}$ Having established that the purposes of the ILO could not have been achieved without an extension of its regulation to the work in agriculture, the Court left the possibility open that the parties had made a mistake by asking for industrial experience as the qualification for the Compliance Committee.

In the Advisory Opinion on Certain expenses of the United Nations the ICJ remarked that the provisions of the treaty as a whole can implicitly supplement a particular provision..$^{51}$ The approaches of the ICJ to interpretation in the preliminary objection phase and the second phase of the South West Africa cases differed substantially, but they were identical in considering the text as not sacrosanct. In the preliminary objection phase, the ICJ gave primacy to "the spirit, context and object" over method of "natural and ordinary meaning". ${ }^{52}$ In the second (admissibility) phase the ICJ deleted some words from the text, contrary to the principle

${ }^{49}$ Competences of the International Labour Organization concerning the Conditions of Labour in Agriculture, 1922 PCIJ Series B, No 2, 37.

${ }^{50}$ Ibid.

${ }^{51}$ Certain expenses of the United Nations (Article 17, paragraph 2, of the Charter), Advisory Opinion 20 July 1962, IC.J Reports, 1962, 159.

${ }^{52}$ South West Africa Cases (Ethiopia v. South Africa; Liberia v. South Africa), Preliminary Objections, Judgment, 21 December 1962, ICJ Reports, 1962, 335. 
effet utile, to adjust the meaning to the Court's interpretation..$^{53}$ Interpreting Article 41 of the Statute of the ICJ to see whether preliminary measures of protection are binding in the La Grand case, the Court faced terms "the measures suggested" in the English version of the second paragraph of Article 41, which implied non binding character. Since the French version "l'indication de ces measures" was neutral to the question of their binding force, the Court reconciled two linguistic versions in light of object and purpose of the Statute and found that the measures were binding. ${ }^{54}$

Both Courts frequently used methods of consulting the purpose, object and context in interpretation of such sorts of treaties. In the Advisory Opinion on the Competences of the ILO, the PCIJ gave primacy to the text of Part XIII of the Versailles Treaty as whole over consideration of particular provisions in isolation ${ }^{55}$ and attributed particular weight to object of the treaty, "general design of the Contracting parties" ${ }^{56}$, and the purposes of the ILO, as stated in the preamble. ${ }^{57}$ In the Organization and Methods of Agricultural Production, the Court referred to the object and purposes for which the ILO was established. ${ }^{58}$ The Court found in the Personal Work of Employers case that prohibition of the incidental regulation of working conditions of employers, if necessary to protect wage-earning workers, would have been contrary to the aim and the scope of Part XIII. ${ }^{59}$ In the Reparation for injuries suffered in the service of the United Nations, the ICJ considered the whole text of the UN Charter ${ }^{60}$ and concluded that the Organization "could not carry the intentions of its founders if it would devoid of international personality." 61 The broad context of Article 17 of the UN Charter ${ }^{62}$ and the purposes of the $\mathrm{UN}^{63}$ played a crucial role in the interpretation of the second paragraph of Article 17 in the Certain expenses of the United Nations case. The text of the provisions on functions, ${ }^{64}$ the object and preamble of the Constitution ${ }^{65}$ of the

\footnotetext{
${ }^{53}$ South West Africa, Second Phase, Judgment, ICJ Reports, 1966, 42.

${ }^{54}$ LaGrand (Germany v. United States of America), Judgment, 27 June 2001, IC J Reports, 2001, 502, paras $100-102$.

${ }^{55}$ Competences of the ILO, supra note 49, at 23.

56 Ibid.

${ }^{57}$ Ibid., at 25.

${ }^{58}$ Organization and Methods of Agricultural Production, 1922 PCIJ, Series B. No. 3, at 57.

${ }^{59}$ Competence of the International Labour Organization to Regulate, Incidentally, the Personal Work of the Employer, 1926 PCIJ, Series B, No. 13, at 18.

${ }^{60}$ Reparation for injuries suffered in the service of the United Nations, Advisory Opinion, 11 April 1949, I.C. J. Reports, 1949, 179.

${ }^{61} \mathrm{Ibid}$.

${ }^{62}$ Certain expenses of the United Nations (Article 17, paragraph 2, of the Charter), Advisory Opinion, 20 July 1962, I.C. J. Reports, 1962, 162.

${ }^{63}$ Ibid., at 167.

${ }^{64}$ Legality of the Use by a State of Nuclear Weapons in Armed Conflict, supra note 45, at 75.

${ }^{65}$ Ibid., at 76.
} 
WHO had a dominant position in Legality of the Use by a State of Nuclear Weapons in Armed Conflict. The purpose and object of the Statute of the ICJ and of its Article 41 had decisive significance in determining the obligatory character of preliminary measures of the protection in the LaGrand case. ${ }^{66}$ The Courts did not explicitly refer to the principle of effectiveness, but need to make the international organizations effective in sense that they are capable for achieving their aims, underlie the reasoning of the Courts.

Much more weight was attributed to the practice in the application of the treaty than to preparatory work. Having found that "as regards the inclusion of agriculture", there was no ambiguity in Part XIII, considered as a whole, the Court observed that "if there were any ambiguity" the action taken under the Treaty might have been explored ${ }^{67}$ and the Court referred shortly to the practice. The Court did not consider preparatory work in the case, but noted there was nothing in the preparatory work that would be contrary to its interpretation. ${ }^{68}$ The practice, especially the conclusion of conventions by the UN, was taken as evidence of understanding of the character of the Organization by its Members. ${ }^{69}$ Practice in the application of the Charter played the role in Certain expenses of the United Nations..$^{70}$

The conclusion might be drawn from the above review that the model of interpretation of constituent acts of international organizations gives priority to the broad context, object and purpose of the treaty and to the practice in the application of the treaty. ${ }^{71}$

However, there are a number of cases of interpretation of such kind of treaties that did not follow the described model. In advisory opinions on the Workers' Delegate, ${ }^{72}$ Admission of a State to the United Nations ${ }^{73}$ or Competence of Assembly regarding admission to the United Nations ${ }^{74}$ the focus of interpretation was on the particular provision and its narrower context, except in the last case where the ICJ analyzed provisions of the UN Charter on the relationship between the General Assembly and the Security Council. The method of ordinary meaning of

${ }^{66}$ LaGrand, supra note 53, at 503, para. 102.

${ }^{67}$ Competences of the International Labour Organization concerning the Conditions of Labour in Agriculture, supra note 48, at 39.

${ }^{68}$ Ibid., at 41.

${ }^{69}$ Reparation for injuries suffered in the service of the United Nations, supra note 59, at 179.

${ }^{70}$ Certain expenses of the United Nations (Article 17, paragraph 2, of the Charter), Advisory Opinion of 20 July 1962, supra note 61, at 160.

${ }^{71}$ See another view on the matter at P. Quayle, Treaties of a Particular Type: The ICJ's Interpretative Approach to the Constituent Instruments of International Organizations, Leiden Journal of International Law, 3/2016, 853 - 877.

72 Workers' Delegate, 1922 PCIJ, Series B, No. 1, at 9.

${ }^{73}$ Admission of a State to the United Nations (Charter, Art. 4), Advisory Opinion, 28 May 1948, IC J Reports, 1948, 58.

${ }^{74}$ Competence of Assembly regarding admission to the United Nations, Advisory Opinion, 3 March 1950, ICJ Reports, 1950, 5. 
terms held main significance. The purpose and object of the treaty, the preamble or the text of the treaty as whole were not considered.

\section{AN INTERPRETATIVE MODEL FOR THE EUROPEAN CONVENTION ON HUMAN RIGHTS}

Exploration of the interpretative practice of the ECtHR has shown that relevant characteristics of the European Convention on Human Rights give priority to some means of interpretation. That practice is known as "evolutive" interpretation. ${ }^{75}$ The ECtHR emphasized the distinguished nature of the Convention saying that: "Unlike international treaties of the classic kind... It creates, over and above a network of mutual, bilateral undertakings, objective obligations which, in the words of the Preamble benefit from a 'collective enforcement'."'76 The Convention is "a 'constitutional instrument of European public order' in the field of human rights". ${ }^{77}$ Its substantive and those provisions "which govern the operation of the Convention's enforcement machinery" have to be interpreted "in the light of present-day conditions," "the Court cannot but be influenced by the developments and commonly accepted standards" 78 and, consequently the Convention cannot be interpreted "solely in accordance with the intentions of their authors as expressed more that forty years ago". ${ }^{79}$ It means that evidence of expressed intention of the parties many decades ago have less significance than evidence of the contemporary understanding of the text. Contemporary understanding is expressed in national legislation of the parties, in treaties, other rules of international law, or other documents which are not binding, etc. The text of the European Convention of Human Rights, general and abstract, usually does not offer information relevant to answer the specific, concrete question and therefore the ordinary meaning

${ }^{75}$ S.C. Prebensen, 'Evolutive interpretation of the European Convention on Human Rights', in P. Mahoney at al., (eds) Protecting Human Rights: The European Perspective, 2000, 1123; G. Letsas, The Truth in Autonomous Concepts: How To Interpret the ECHR, European Journal of International Law, 2/2004, 279; A. Mowbray, The Creativity of the European Court of Human Rights, Human Rights Law Review, 1/2005, 57; C.L. Rozakis, The European Judge as Comparatist, Tulane Law Review, 2005 - 2006, 257; P.M. Dupuy , supra note 33, at 133 - 136; G. Letsas, Strasbourg's Interpretative Ethic: Lessons for the International Lawyer, European Journal of International Law, 3/2010, 509; K. Dzehtsiarou, European Consensus and the Evolutive Interpretation of the European Convention on Human Rights, German Law Journal, 10/2011, 1730.

${ }^{76}$ ECtHR Loizidou v. Turkey, Appl. no. 15318/89, Judgment of 18 December 1996, at para. 70. All ECtHR decisions are available online at http://hudoc.echr.coe.int/

${ }^{77}$ Loizidou, supra note 75, at para 75; ECtHR Bosphorus Hava Yollarl Turizm ve Ticaret Anonim Şirketi v. Ireland, Appl. no. 45036/98, Judgment of 30 June 2005, at para. 156; Al-Dulimi and Montana Management Inc. v. Switzerland, Appl. no. 5809/08, Judgment of 21 June 2016, at para. 145.

${ }^{78}$ Tyrer v. United Kingdom, Appl. no. 5856/72, Judgment of 25 April 1978, at para. 31.

${ }^{79}$ Loizidou, supra note 75, at para. 71. 
method is not frequently used. It does not mean that the text of Convention is irrelevant. Thus, for example, the ECtHR stated: "Article 2 cannot, without a distortion of language, be interpreted as conferring the diametrically opposite right..." 80

When the ECtHR found that national practice relevant for the application of the provision of the Convention of majority of the parties converges enough in respect to the specific disputed issue, the Court named that converging practice as the "European consensus", "broad consensus", "emerging consensus", or "common ground" and took it as evidence of understanding of the parties of the concerned provision in relation to the specified issue. ${ }^{81}$ The ECtHR states: "The consensus emerging from specialised international instruments and from the practice of Contracting States may constitute a relevant consideration for the Court when it interprets the provisions of the Convention in specific cases." 82 In the case of absence of consensus, the ECtHR usually leaves the matter in the "margin of appreciation", at discretion of each Contracting State..$^{83}$

It should be noted that the practice in the application of the Convention, used by the ECtHR as means of interpretation is not fully in line with standards inserted in the VCLT and explained by the ILC. In the Loizidou (jurisdiction) case, the ECtHR invoked Article 31 (3 (b)) of the VCLT ${ }^{84}$ which refers to subsequent practice in the application of the treaty as an authentic means of interpretation. However, the judgment informed that there were two exceptions, together with the Respondent State, from a consistent practice of other parties. The disharmonic practice of three parties obviously disabled a finding of common understanding of all parties, which was the condition of Article 31 (3 (b)) of the VCLT. "The consensus emerging from ... the practice of Contracting States" can be treated as a supplementary means of interpretation. But, even such treatment requires some flexibility. The ILC took perhaps too much of a restrictive position that the identification of subsequent practice as a supplementary means of interpretation "requires, in particular, a determination whether conduct by one or more parties is in the application of the treaty." 85 A huge majority of national legislative and para 39.

${ }^{80}$ ECtHR, Pretty v. The United Kingdom Appl. no. 2346/02, Judgment of 29 April 2002,

${ }^{81}$ R. Etinski, 'Subsequent Practice in the Application of the Convention for the Protection of Human Rights and Fundamental Freedoms as a Means of its Interpretation', in R. Keca (ed.), Thematic Collection of Papers, Harmonisation of Serbian and Hungarian Law with the European Union Law, 2015, 17.

82 ECtHR Magyar Helsinki Bizottság v. Hungary, Appl. no. 18030/11, Judgment of 8 November 2016, at para 124 .

${ }^{83}$ ECtHR Hämäläinen v. Finland, Appl. no. 37359/09, Judgment of 16 July 2014, at para. 67; ECtHR S.H. and others v. Austria, Appl. no. 57813/00, Judgment of 3 November 2011, at para. 94.

${ }^{84}$ Loizidou, supra note 75 , at para. 73.

${ }^{85}$ Text of the draft conclusions on subsequent agreements and subsequent practice in relation to the interpretation of treaties adopted by the Commission, Conclusion 6 para 3, RILC, 2016, 120. 
other national legal acts are not taken in direct application of the Convention, usually they have not been taken for the implementation of the Convention than for other purposes, but they have to be in accordance with the Convention.

Stressing often "that it is essential that the Convention is interpreted and applied in a manner which renders its rights practical and effective and not theoretical and illusory," the ECtHR provides extensive interpretation ${ }^{86}$ and requires that particular circumstances of the situation do not prevent effect of the Convention. ${ }^{87}$ That dictum has its origin in contextual interpretation, in establishing the connection between Article 1 of the Convention, which obliges the parties "to secure the practical and effective protection of the rights and freedoms..." and other Articles so that the connection resulted in disclosing "positive" obligations. ${ }^{88}$

However, that does not mean that the ECtHR did not and will not use other means for interpretation of the European Convention on Human Rights. The preparatory work is usually not employed, but sometimes is. The ECtHR has determined its position in the model: "It can be seen from the case-law that the travaux préparatoires are not delimiting for the question whether a right may be considered to fall within the scope of an Article of the Convention if the existence of such a right was supported by the growing measure of common ground that had emerged in the given area." 89 It might mean that practice in the application of the Convention, as a supplementary means, in the variant used by the ECtHR, or other evidence of contemporary understanding of the parties prevails over the preparatory work.

Without pretension to be exhaustive in drawing all details of the interpretative model, established by the ECtHR, it can be concluded that it prioritizes contemporary expressions of understanding of the text of the Convention, made by the Contracting Parties.

In the case of departure from the model the ECtHR might be expected to provide an explanation. So, for example, in the Bankovic case, the Court departed from key elements of the model, established in the Loizidou (jurisdiction) case, particularly from its thesis that evolutive interpretation is not relevant just for substantive provisions only, but also for those "which govern the operation of the Convention's enforcement machinery", and explained:

"However, the scope of Article 1, at issue in the present case, is determinative of the very scope of the Contracting Parties' positive obligations and, as such,

${ }^{86}$ Magyar Helsinki Bizottság v. Hungary, supra note 81, at para. 121.

${ }^{87}$ ECtHR Paposhvili v. Belgium, Appl. no. 41738/10 Judgment of 13 December 2016, at para 182; ECtHR Nada v. Switzerland, Appl. no. 10593/08, Judgment of 12 September 2012, para. 195.

${ }^{88}$ ECtHR Osman v. United Kingdom, Appl. no. 23452/94, Judgment of 28 October 1998, para. 116; ECtHR Assenov and others v. Bulgaria, Appl. no. 24760/94, Judgment of 28 October 1998, para. 102.

${ }^{89}$ Magyar Helsinki Bizottság v. Hungary, supra note 81, at para 125. 
of the scope and reach of the entire Convention system of human rights' protection as opposed to the question, under discussion in the Loizidou case (preliminary objections), of the competence of the Convention organs to examine a case." 90

The explanation lies in different functions of Article 1 of the European Convention on Human Rights, on one side, and its former Articles on jurisdiction of the Commission and the Court, ${ }^{91}$ on the other side. It is evidence of the ECtHR conviction that the function or the scope of effect of the provision of the Convention is of relevance for the choosing means of interpretation.

\section{AN INTERPRETATIVE MODEL FOR THE INVESTMENT TREATIES}

It is not easy to establish statistical correlations between investment treaties and the means of their interpretation in arbitral practice. Three empiric investigation of interpretation of these treaties did not result in identical outcomes. It should be noted however that the investigations differed in respect of the scope of samples of the reviewed arbitral decisions and awards, in respect of the period when the decisions were rendered and in respect of investigative methodology. However some findings do converge. The biggest sample includes 229 arbitral decisions and awards..$^{92}$ The sample of the second size covers 98 decisions or awards rendered by the ICSID tribunals between 1998 and $2006 .{ }^{93}$ The smallest sample contains 20 decisions and awards of the ICSID tribunal delivered between 2011 and $2016 .{ }^{94}$

The first and the third investigations discovered the use of methods of ordinary meaning and context in about $60 \%$ of reviewed cases. ${ }^{95}$ According to these two explorations a bigger employment had only had previous case law which was referred to in about $80 \%$ of reviewed decisions. Fauchald did not speak on the

${ }^{90}$ ECtHR Bankovic and others v. Belgium and others, Appl. no. 52207/99, Decision of 12 December 2001, at para. 65 .

${ }^{91}$ See critical observations at A. Orakhelashvili, Restrictive Interpretation of Human Rights Treaties in the Recent Jurisprudence of the European Court of Human Rights, European Journal of International Law, 3/2003, 538 -551.

92 T. Hai Yen, The Interpretation of Investment Treaties, in L. Malintroppi, E. ValenciaOspina (eds) 7 International Litigation in Practice, 2014.

${ }^{93}$ O.K. Fauchald, The Legal Reasoning of ICSID Tribunals - An Empirical Analysis, European Journal of International Law, 2/2008, 301.

${ }^{94} \mathrm{R}$. Etinski, Sredstva tumačenja međunarodnih ugovora koja primenjuju ICSID arbitraže, Pravni život 12/2016, 73.

95 T. Hai Yen, op. cit., at 46, 53; Etinski, op. cit., at 83. 
ordinary meaning but said that the objective interpretation was prevailing. ${ }^{96} \mathrm{Un}-$ der objective interpretation he most probably understood textual interpretation. Actually he illustrated an objective interpretation on the factual basis that the tribunal used dictionaries. ${ }^{97}$ Further, he observed usage of context in about fifty decisions. ${ }^{98}$ Evidence of the scrupulous adherence to the words was the frequent reference to the principle of effet utile. Fauchald and Etinski explorations noted the reference to effet utile in about $20 \%{ }^{99}$ or $30 \%{ }^{100}$ of the reviewed decisions.

Fauchald ${ }^{101}$ and Etinski ${ }^{102}$ investigations disclosed employment of the object and purpose in about $50 \%$ of the reviewed case. Hai Yen observed that method just in $35 \%$ of the reviewed cases. ${ }^{103}$ Using comparative treaty practice (comparisons with other investment treaties) was detected in about $30 \%$ by Fauchald ${ }^{104}$ and in $45 \%$ by Etinski. ${ }^{105}$ References to the scholarly writings were observed in more than $70 \%$ of the reviewed decisions by Fauchald, ${ }^{106}$ in $44 \%$ by Hai Yen ${ }^{107}$ and in $35 \%$ by Etinski. ${ }^{108}$ Fauchald found the preparatory works in something less than $30 \%,{ }^{109}$ Etinski in $15 \%{ }^{110}$ and Hai Yen in some more than $5 \%$ of the reviewed cases. References to the subsequent agreements or to the subsequent practice in the application of the treaty were very exceptional.

Bearing in mind that, in comparison with the constituent acts of international organizations and the European Convention on Human Rights, investment treaties govern the smaller scope of social interactions, which are limited to relationships between a State and the foreign investors, it might be expected that the parties to such kind of treaties could much more precisely express their intention in the text of a treaty and consequently that methods of ordinary meaning and context had greater weight in the interpretation of these treaties. The three investigations show that this expectation might have some support in arbitral practice. In the Ping An Life Insurance Company of China case, the ICSID Tribunal confirmed the importance of the ordinary meaning method:

\footnotetext{
${ }^{96}$ O.K. Fauchald op.cit., at 316.

97 Ibid.

${ }^{98}$ Ibid., at 321.

${ }^{99} \mathrm{Ibid}$, at 318

${ }^{100}$ R. Etinski, op. cit., at 83.

${ }^{101}$ O.K. Fauchald op.cit., at 322.

102 R. Etinski, op. cit., at 83.

103 T. Hai Yen, op. cit., at 64.

${ }^{104}$ O.K. Fauchald op.cit., at 345.

${ }^{105}$ R. Etinski, op. cit., at 85.

${ }^{106}$ O.K. Fauchald op.cit., at 351.

${ }^{107}$ T. Hai Yen, op. cit., at 71.

${ }^{108}$ R. Etinski, op. cit., at 85.

${ }^{109}$ O.K. Fauchald, op.cit., at 349.

${ }^{110}$ R. Etinski, op. cit., at 85.

111 T. Hai Yen, op. cit., at 67.
} 
"The ordinary meaning approach has been adopted in many investor-State arbitrations to confirm that the presumed intentions of the parties should not be used to override the explicit language of a BIT (Fraport v. Philippines at [340]) or to override the agreed upon framework (Daimler Financial Services $v$. Argentina at [164]), or be used as an independent basis of interpretation (Wintershall v. Argentina at [88])."112

The ICSID Tribunal reminded the parties in the Mobil Investments Canada case that "Articles 31 and 32 of the VCLT attaches the greatest importance for interpretation to the ordinary meaning of the treaty, taken in its context." 113 That interpretative instruction, given by the Tribunal, is meaningful particularly in respect to investment treaties. As the provisions of a treaty completely express the intention of the parties, there is not great need to consult the object and purposes of the treaty for obtaining further information. In spite of that empirical investigation disclosed that the object and purposes of a treaty have been relatively frequently used in the interpretation. The ICSID tribunals quote often first paragraph of Article 31 of the VCLT which refers to the object and purpose of the treaty. Fauchald came to the impression that the teleological method was "subsidiary to the objective approach", 114 in other words the purposes were used for interpretation when the text was not clear. Also the tribunals used the object and purpose to control correctness of the interpretation arrived at by using ordinary meaning and context. ${ }^{115}$ The object and purpose prevail over the wording of the treaty exceptionally. ${ }^{116}$ Small employment of the preparatory works and the practice in the application of the treaty is unexpected.

These treaties contain some legal notions and standards, such as investment, property, expropriation, national treatment, denial of justice, which have autonomous meaning in investment treaties if they are not defined in the specific way in a particular treaty. The ICSID tribunals determine their meaning mainly by referring to the case law of ICSID and other tribunals, by analyzing comparative treaty practice or by reading scholarly works. Sometimes the ICSID tribunals differ between consistent previous arbitral practices - jurisprudence constant and inconsistent practice attributing importance to consistent practice.

112 ICSID, Ping An Life Insurance Company of China, Limited and Ping An Insurance (Group) of China, Limited v. Kingdom of Belgium - Award, 30 April 2015, ICSID Case No. ARB/12/29, para. 166. The same position in ICSID, Ömer Dede and Mr. Serdar Elhüseyni v. Romania-Award, 5 September 2013, ICSID Case No. ARB/10/22, para. 210.

${ }^{113}$ ICSID Mobil Investments Canada Inc. \& Murphy Oil Corporation v. Canada-Decision on Liability and on principles of quantum, 22 May 2012, ICSID Case No. ARB(AF)/07/4, para. 232.

${ }^{114}$ O.K. Fauchald, op.cit., at 316.

115 Ibid., at. 323.

${ }^{116}$ Ibid. See criticism concerning teleological method at S. Djajić, Searching for purpose: Critical assessment of teleological interpretation of treaties in investment arbitration, International Review of Law, 2016, available at http://dx.doi.org/10.5339/irl.2016.iit.4 (Last visited 20. 09. 2017) 
Thus the interpretative model for the investment treaties would give preference to the text of a treaty, to the methods of ordinary meaning and context. The consistent case law and scholarly writings have particular weight in interpreting autonomous concepts of international investment law.

\section{CHARACTERISTICS OF THE QUESTION APPEARED IN THE APPLICATION OF A TREATY AS THE DETERMINANT OF THE SIGNIFICANCE OF MEANS OF INTERPRETATION}

At the beginning of its work the PCIJ was asked to give advisory opinions concerning three questions related to Part XIII of the Versailles Peace Treaty. The first question was: "Was the Workers' Delegate for the Netherlands at the Third Session of the International Labour Conference nominated in accordance with the provisions of paragraph 3 of Article 389 of the Treaty of Versailles?"117 The second question read: "Does the competence of the International Labour Organisation extend to international regulation of the conditions of labour of persons employed in agriculture?" And the third question: "Does examination of proposals for the organization and development of methods of agricultural production, and of other questions of a like character, fall within the competence of the International Labour Organisation ?" 118 The PCIJ answered the first question by the first Advisory Opinion of 31 July 1922 and the other two questions were answered by the second and third Advisory Opinion of 12 August 1922. Concerning the last two questions, which were answered in the same day, the PCIJ noted that "they are essentially different in their nature, and the considerations applicable to them are different". ${ }^{119}$ In fact the difference was bigger between the first and other two questions. The first question related to the particular provision in Article 389 of the Versailles Treaty. The other two questions did not refer to a particular provision. Thus, naturally the first question directed the PCIJ to the particular provisions of Article 389 which became the subject matter of its attention and the Court investigated "the ideas inspiring the provisions", ${ }^{120}$ object of these provisions, ${ }^{121}$ wording of the Article, ${ }^{122}$ and rejected absurd ${ }^{123}$ and ineffective solutions. ${ }^{124}$ The other two questions were not directed to a particular Article, but asked about the limits of competences of the ILO. Since the

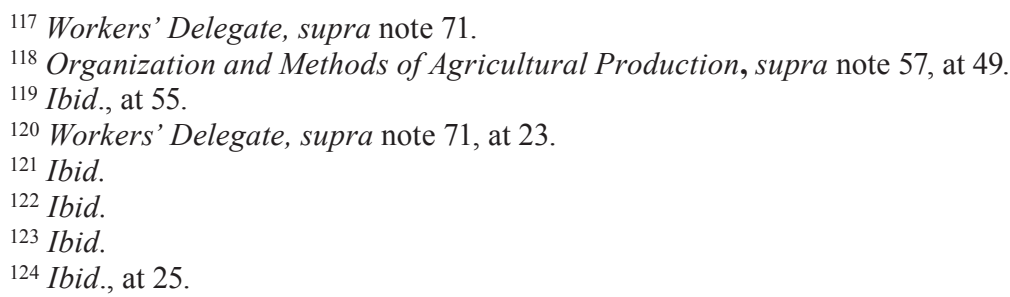


aims, expressed in the preamble of Part XIII, inform about the limits of the competences, the Court consulted these provision to arrive at the answers.

In the Admission of a State to the United Nations case the question sent to the ICJ related to Article 4, Paragraph 1 of the UN Charter and the Court investigated the text of the Paragraph ${ }^{125}$ in the context and sprit of the second paragraph of the same Article ${ }^{126}$ and by applying the method of ordinary meaning came to the conclusion that the text was sufficiently clear to give a precise answer. The Court rejected looking at the preparatory work.

However, if the question relates to the particular Article of a constituent act, it does not necessary mean that the broader context and purposes of a treaty are irrelevant in all cases. Considering the question in the Competence of Assembly regarding admission to the United Nations case, which related to paragraph 2 of Article 4 of the Charter, the ICJ investigated the broader context of the Article to confirm the conclusions about the clarity of the text of paragraph 2 of Article 4. In the Certain expenses of the United Nations case, concerning Article 17, paragraph 2 of the Charter, the ICJ consulted the broad context of the Article ${ }^{127}$ and used purposes of the United Nations ${ }^{128}$ to determine the meaning of the expenses of the Organization.

The interpretative practice of the ECtHR reveals that certain characteristics of the questions, which have to be answered by interpretation of the European Convention on Human Rights, can justify that the ECtHR departs from some elements of its interpretative model. It was said above that the converging practice in the application of the Convention, as an expression of contemporary understanding of the Convention by majority of the Contracting Parties, has important role in the interpretation of the Convention. However, it is not always the case. In $A, B$ and $C$ v. Ireland, the Court found that "the prohibition in Ireland of abortion for health and well-being reasons, based as it is on the profound moral views of Irish people as to the nature of life..."129 makes the opposite widespread consensus among the Parties without relevance. Or, in Republican Party of Russia v. Russia, the Court considered that practice in the Parties reflected a consensus that regional political parties should have been allowed to be established. But, the Court found that "notwithstanding this consensus, a different approach may be justified where special historical or political considerations exist which render a more restrictive practice necessary". ${ }^{130}$ Thus, if the question affects "the profound

${ }^{125}$ Admission of a State to the United Nations (Charter, Art. 4), supra note 72, at 62.

126 Ibid., at 63.

${ }^{127}$ Certain expenses of the United Nations (Article 17, paragraph 2, of the Charter), supra note 50 , at 162 .

128 Ibid., at 167 .

${ }^{129}$ ECtHR A,B and C v. Ireland, Appl. no. 25579/05, Judgment of 16 December 2010, at para. 241.

${ }^{130}$ ECtHR Republican Party of Russia v. Russia, Appl. no. 12976/07, Judgment of 11 April 2011, at para. 126. 
moral views" of people, stability of new born democratic system or something of similar nature, such nature of the question can justify leaving of European consensus as a means of interpretation. If the subject matter of the question is concerns the issue of "autonomous concept," developed by the ECtHR, the answer will be in line with this autonomous concept.

If the question relates to arbitration clauses of investment treaties, ordinary meaning and context of the clause will have particular importance, but if the question concerns autonomous concepts of international investment law consistent case law and scholarly writings will have prevailing weight.

Obviously, the choice of means of interpretation and attribution to them corresponding weight depends in some measure on the characteristics of the question which has to be answered by interpretation.

\section{CHARACTERISTICS OF MEANS OF INTERPRETATION AS DETERMINANT OF THEIR SIGNIFICANCE}

\subsection{Characteristics of Means of Interpretation as Determinants of Their Relevance}

Having in view that Article 32 of the VCLT enumerates supplementary means of interpretation in an exemplary way and that the list of these means is open, the issue might be whether it is possible to identify determinants of relevance of supplementary means of interpretation. In other words the issue is whether we can know in advance what facts, beyond these determined in Articles 31 and 32, are relevant for interpretation of a treaty provision? If we take Villiger's assertion that state parties are the masters of the treaty ${ }^{131}$ as a starting point, if the treaty is a product of their will and remains under control of their will, the means of interpretation may include all evidences of facts that might be connected with their will, as the products of their will or determinants of their will. Such understanding is in accordance with the ICJ definition of interpretation: "a treaty provision ... must be interpreted ... in accordance with the intentions of its authors as reflected by the text of the treaty and the other relevant factors in terms of interpretation". 132 However, that definition was given in the context of the bilateral treaty and we have seen that the ICJ distinguished constituent acts of international organizations due to particular characteristics of these treaties, among which is also that an international organization, founded by a treaty, enjoys autonomy in application and interpretation of the treaty. It means that State Parties to such kind of treaties are not

${ }^{131}$ M. E. Villiger, supra note 17, at paras 46, 384 and 429.

${ }^{132}$ Dispute regarding Navigational and Related Rights (Costa Rica v. Nicaragua), Judgment of 13 July 2009, ICJ Reports (2009), 213, at 273, para 48. 
exclusive masters of these treaties, at least, not in a way as they are masters of other treaties. Qualifying the European Convention on Human Rights as "a constitutional instrument of European public order", the ECtHR displaced the Convention beyond the exclusive circle of the will of the State Parties, in a much broader circle of facts that may be taken into account for interpretation. The Court considers reports of non-governmental organizations, scientific reports, material of the Council of Europe etc. In the Christine Goodwin case the ECtHR took into account legislative changes in Singapore, Canada, South Africa, Israel, Australia, New Zealand and the United States of America, ${ }^{133}$ obviously states beyond the circle of the State Parties to the European Convention on Human Rights. Even more remote facts have been mentioned in literature, such as moral values underling the treaty, ${ }^{134}$ "the general features of the world social and power processes" 135 and the expectation of the audiences of different dispute settlement bodies. ${ }^{136}$

On the other hand, we can find in judicial practice examples of refusal of the court to go far beyond the text of the treaty. In the case of the Competences of the ILO to regulate incidentally the personal work of the employer, the PCIJ considered that "political principles or social theories" which were not mentioned in the treaty were not of relevance for ascertaining what the contracting parties agreed to. ${ }^{137}$

The attitude of the parties to the dispute may play a particular role in the determination of significance of the means of interpretation. In the Article 3, Paragraph 2, of the Treaty of Lausanne case, the PCIJ found that the text of Article 3 was sufficiently clear, which made consideration of the preparatory work redundant, but since the Turkish Government referred to some facts of negotiations of the Lausanne Treaty, the Court investigated the preparatory work. ${ }^{138} \mathrm{~A}$ failure of the council for the claimant in the Kllıç case to address properly the new evidence of the understanding of the Russian version of the BIT, submitted by the respondent, has proved fatal for the claimant. An attempt of the council to remedy the failure in an annulment procedure was not successful, since the ad hoc Committee found that: "An annulment proceeding is not the appropriate venue for the losing party in ICSID arbitration to make up for failures of the strategy followed by counsel in the arbitration proceeding." 139

${ }^{133}$ ECtHR Christine Goodwin v. United Kingdom, Appl. no. 28957/95, Judgment 11 July 2002, at para. 56 .

${ }^{134}$ Letsas, supra note 74.

${ }^{135}$ M. S. McDougal, H. D. Lasswell and J. C. Miller, supra note 16, at 96.

${ }^{136} \mathrm{G}$. Nolte, supra note 18 , at 140.

137 Competence of the International Labour Organization to Regulate, Incidentally, the Personal Work of the Employer, supra note 58, at 23.

${ }_{138}$ Article 3, Paragraph 2, of the Treaty of Lausanne, 1925 PCIJ, Series B, No. 12, at 22.

${ }_{139}$ ICSID Kılıç Inşaat Ithalat İhracat Sanayi ve Ticaret Anonim Şirketi v. TurkmenistanDecision on Annulment, 14 July 2015, ICSID Case No. ARB/10/1, para. 110. 
Beyond these considerations there are at least two general characteristics of the means of interpretation which determine their relevance in the broadest sense. Obviously, if the means of interpretation does not extend any information which might be useful for answering the question raised in the application of a treaty, such means is then without relevance. Another characteristic is accessibility. If relevant material was not accessible to a State, if a State could not have knowledge of material before the disputed event occurred, it would not be fair to take it into account for interpretation. It was explicitly said concerning the preparatory work, ${ }^{140}$ but it is not easy to see any reason against general validity.

\subsection{Characteristics of the Means of Interpretation as Determinants of Their Weight}

Discourse on the significance of various evidences of intention of the parties was running across the pages of three issues of the American Journal of International Law in 1929. In editorial comment $\mathrm{Ph}$. M. Brown disagreed with the US official who asserted that "interpretations," "understandings," "precisions," and "constructions," by which all signatories, except the US, conditioned their acceptance of the Pact on the Renunciation of War of 1928, did not touch the text of the Pact. ${ }^{141}$ Brown emphasized the importance of detection of "real intention of the parties" for interpretation of international treaties. ${ }^{142}$ In the next issue of the Journal, A. P. Fachiri replied stressing almost exclusively the relevance of the text of a treaty. He grounded such an approach not only in legal certainty which was, according to him, more important in international than in domestic affairs, but also in conditions of the conclusion of a treaty, on the fact that members of legislative body, by whose consent a state accepts a treaty, did not participate in negotiations and could not be familiar enough with all the details of the preparatory work which might be relevant for interpretation. ${ }^{143}$ In his response in the next issue of the Journal Brown did not concur with Fachiri's opinion that, provided that the text of a treaty was "intelligible," extraneous evidence could not be used for its interpretation. According to Brown the text could not be taken as sufficiently clear before interpreter found that the meaning embodied the intent of the parties. ${ }^{144}$

${ }^{140}$ M.E. Villiger, supra note 1, at113.

Sbolci, supra note 2, at 156.

${ }^{141} \mathrm{Ph}$. M. Brown, The Interpretation of the General Pact for the Renunciation of War, American Journal of International Law, 1929, 376.

${ }^{142}$ Ibid., at 377.

143 A.P. Fachiri, Interpretation of Treaties, American Journal of International Law, 1929, 746.

${ }^{144} \mathrm{Ph}$. M. Brown,The Interpretation of Treaties, American Journal of International Law, 1929,820 . 
Something of the same discourse revived itself three years later in the differences between the majority and a minority of the judges of the PCIJ concerning the advisory opinion in the case of the Interpretation of the Convention of 1919 concerning Employment of Women during the Night. ${ }^{145}$ Interestingly, Fachiri appeared in the proceedings as the representative of the UK. ${ }^{146}$ The PCIJ found that the text of Article 3 of the Convention was free from ambiguity and obscurity, ${ }_{147}$ but contrary to Fachiri's position, the Court searched for "some valid ground for interpreting the provision otherwise than in accordance with the natural sense of the words." 148 The PCIJ investigated title, preamble, other provisions of the Convention ${ }^{149}$ the aim, preamble and other provisions of Part XIII of the Versailles Treaty, ${ }^{150}$ previous case law of the PCIJ related to the ILO, ${ }^{151}$ circumstances of the conclusion of the Convention, ${ }^{152}$ preparatory work ${ }^{153}$ and comparative practice, ${ }^{154}$ but did not find any good reason to depart from the natural meaning of terms. In spite of the fact that the PCIJ investigated all extraneous evidences, Judge Anzilotti criticized the approach of the Court asserting, in line with Brown, that the satisfactory clarity of the text could not be established without previously ascertaining the intention of the parties and invoking the general aim of international labour legislation - protection of manual workers - as the best evidence of the intention of the parties. ${ }^{155}$ So, he was of the opinion that the Convention did not prevent women in positions of supervision or management to work during the night. The interpretation of the majority was quite correct, but later practice has shown that Judge Anzilotti read the intention of the parties better than the majority. Two years later, states adopted a revised text of the Convention ${ }^{156}$ and exempted women holding position of management and who were not engaged in manual work from prohibition of night work.

The hierarchical relationship between the "ordinary meaning" rule and other methods of interpretation has been considered by the two World Courts. We have seen that the PCIJ thought that "some valid ground" can justify "interpreting

${ }^{145}$ Interpretation of the Convention of 1919 concerning Employment of Women during the Night, 1932 PCIJ, Series A/B, No. 50, at 373.

${ }^{146} \mathrm{Ibid}$., at 368.

${ }^{147}$ Ibid., at 373 .

148 Ibid.

${ }^{149}$ Ibid.

${ }^{150} \mathrm{Ibid}$., at 374 and 375.

${ }^{151}$ Ibid., at 374 .

152 Ibid., at 376.

${ }^{153}$ Ibid., at 378.

${ }^{154}$ Ibid., at 380 .

${ }^{155}$ Interpretation of the Convention of 1919 concerning Employment of Women during the Night, 1932 PCIJ, Series A/B, No. 50, Dissent Opinion of Judge Anzilotti.

${ }^{156}$ Convention concerning Employment of Women during the Night (Revised), 1934. 
the provision otherwise than in accordance with the natural sense of the words". 157 The PCIJ looked for "valid ground" everywhere in all available evidences, as indicated in the previous paragraph. And, the ICJ stated that "To warrant an interpretation other than that which ensues from the natural meaning of the words, a decisive reason would be required..." ${ }^{158}$ It rejected looking at the preparatory work, in spite of the fact that a minority of judges believed that preparatory work led to the opposite interpretation. Two years later the ICJ observed that "the first duty of a tribunal ....is to endeavour to give effect to them (words) in their natural and ordinary meaning in the context in which they occur. If the relevant words in their natural and ordinary meaning make sense in their context, that is an end of the matter". ${ }^{159}$ In spite of that tough statement, the Court made a short reference to the preparatory work and the practice in the application of the treaty. ${ }^{160}$ After twelve years the same Court said that the rule of the natural and ordinary meaning of the words is not an absolute one. "Where such a method of interpretation results in a meaning incompatible with the spirit, purpose and context of the clause or instrument in which the words are contained, no reliance can be validly placed on it." 161 Thus, the scope of methods that can challenge the "ordinary meaning" rule has varied in the practice of two World Courts from the context, via spirit and purpose to all available evidence. In spite of the mentioned variations, the quoted passages and judicial practice in general conform presumed greater weight of "ordinary meaning" method. At least, it should be the starting point of an interpretation.

The difference between the subsequent practice in the application of the treaty as authentic and supplementary means is clearly established. To be authentic means, subsequent practice has to reflect the common understanding of all parties, but it is not necessary that all parties participate in the practice. In Conclusion 9 [8] of the Text of the draft conclusions on subsequent agreements and subsequent practice in relation to the interpretation of treaties adopted by the Commission the ILC stated that "the weight of a subsequent agreement or subsequent practice as a means of interpretation under article 31, paragraph 3, depends, inter alia, on its clarity and specificity" and that "the weight of subsequent practice under article 31, paragraph 3 (b), depends, in addition, on whether and how it is repeated." 162

${ }^{157}$ Interpretation of the Convention of 1919 concerning Employment of Women during the Night, supra note 144, at 373.

${ }^{158}$ Admission of a State to the United Nations, supra note 72, at 63.

${ }^{159}$ Competence of Assembly regarding admission to the United Nations, supra note 73, at 8. ${ }^{160} \mathrm{Ibid}$., at 9.

${ }^{161}$ South West Africa Cases (Ethiopia v. South Africa; Liberia v. South Africa), Preliminary Objections, supra note 51, at 336.

${ }^{162}$ RILC, supra note 4, at 122. 
Taking authenticity of intention or understanding of the parties as a measure of weight of means of interpretation, the following means from Article 31 - ordinary meaning, context, agreement on interpretation of a treaty and subsequent practice in the application of a treaty - might have presumed greater weight.

\section{CONCLUSIONS}

Articles 31 and 32 of the VCLT leave broad discretion concerning the choice and weighing means of interpretation. But, discretion is not unlimited. The interpreter is not free "to choose how to use and apply the different means of interpretation." 163

Article 31 of the VCLT implies consideration of all means of interpretation which constitute "general rule" of interpretation in any case of interpretation. It does not mean that all of them will be relevant in each case. The relevance of any means of interpretation is determined by its capacity to extend information useful for answering the question appearing in the application of the treaty. Thus, the Villiger stated: "All means in Article 31 should be considered. However, not every means will necessarily yield a result as to the interpretation of the treaty term. The order chosen in Article 31 among the various means therefore appears to be that of logic, proceeding from the intrinsic to the extrinsic, from the immediate to the remote." 164

In spite of the fact that some means of interpretation from Article 31, such as ordinary meaning, context, agreement on the interpretation of a treaty, or subsequent practice in the application of a treaty have, by their authenticity of expression of intention or understanding of the parties, greater weight, it could not be said that they should have in each case primacy over other means.

Exploration of the interpretative practice of different international courts indicates a certain correlation between the nature or other particular characteristics of the treaty and employed means of interpretation, which is expressed in the fact that some means of interpretation are used much more frequently than others and that some are weighted greater than others. The more frequently used and more important means for interpretation of the particular treaty or the particular type of treaties can be named "model of interpretation." Thus, the model of interpretation of constituent acts of international organizations gives priority to the broad context, object and purpose of the treaty and to the practice in the application of the treaty. Or, the model of interpretation of the European Convention of Human Rights extends the limits of sources of information of relevance for inter-

163 Ibid.

164 M.E. Villiger, supra note 1, at 114. 
pretation and prioritizes contemporary expressions of understanding of the text of the Convention. The model of interpretation of investment treaties prioritizes the ordinary meaning, context, consistent case law and scholarly writings.

Beside the nature and particular characteristics of the treaty, the choice of means of interpretation and attribution to them corresponding weight depends in some measure on the characteristics of the question which has to be answered by interpretation.

The model of interpretation in combination with particular characteristics of the question which should be answered by interpretation may produce an expectation in respect of the choice and weight of means of interpretation in the specified case. The ILC referred to the importance of the consistency in interpretation in the sense that the interpreter should consider previous assessments of significance of means of interpretation in comparable cases. ${ }^{165}$ If an interpreter departs from previous assessments of means of interpretation in comparable cases, the public should expect the explanation.

${ }^{165}$ RILC, supra note 4, at 131, para. 15. 
Др Родољуб М. Еӣински, редовни йрофесор

Универзииетеи у Новом Саду

Правни факулиетеи у Новом Саду

R.Etinski@pf.uns.ac.rs

\section{Средства тумачења међународних уговора и детерминанте њиховог значаја}

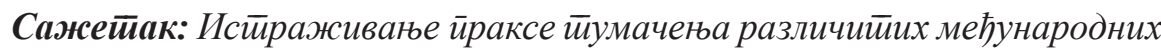
судова йоказује да йостиоји извесна корелачија између ирироде и друг̄их

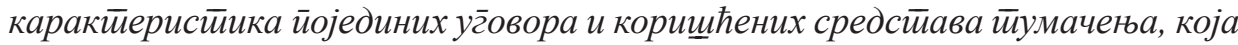
је изражена у чињеници да су нека средстива йумачења корищћена многоо

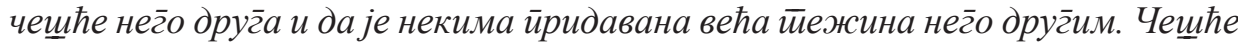
корищћена средстива и средстива којима је ирридаван већи значај у тиумачењу неког̄ йосебног̄ уг̄овора или неких уг̄овора истие врсиие би мог̆ла да се назову

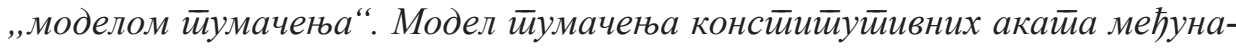

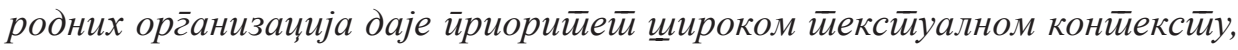
ирредмейу и ииљу уг̃овора као и ирракси иримене уг̄овора. Или, модел йумачења Евройске конвенције о људским иравима щиии границе извора информација

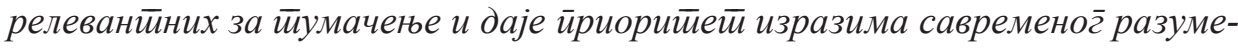

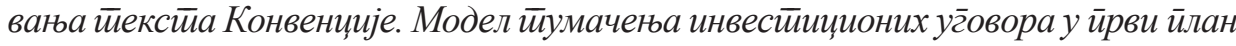

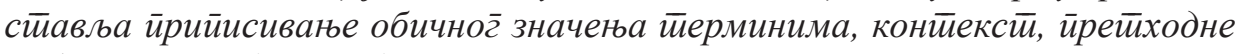
арбитиражне одлуке и докиирину.

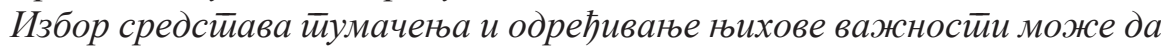

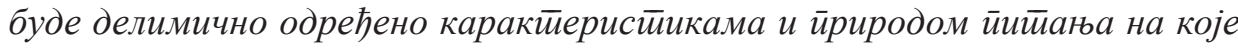

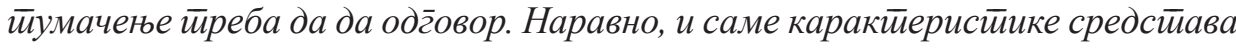

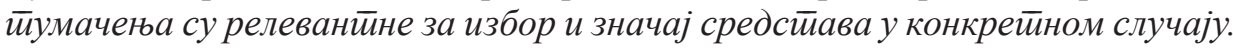

Модел йумачења у комбинацији са ирриродом йостиављеног̄ йийања би

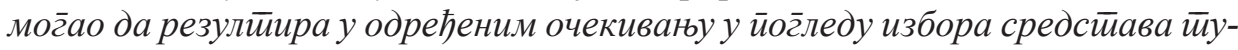
мачена и юиховог̄ вредновања. Уколико би суд одсӣуйио од ӣаквих очекивања, која су заснована на њег̄овор ранијој ирракси, суд би йребао да оиравда йо одсииуйање навођењем убедљивих разлог̄a.

Кључне речи: међународни уг̄овори, средстива тиумачења, значај.

Датум пријема рада: 16.11.2017. 